\title{
Morpho-physiological changes in Billbergia zebrina due to the use of silicates in vitro
}

\author{
ADALVAN D. MARTINS ${ }^{1}$, JOÃO PAULO R. MARTINS ${ }^{2}$, LUCAS A. BATISTA ${ }^{1}$, GABRIELEN M.G. \\ DIAS ${ }^{3}$, MIRIELLE O. ALMEIDA ${ }^{4}$, MOACIR PASQUAL ${ }^{1}$ and HELOÍSA O. DOS SANTOS ${ }^{5}$ \\ ${ }^{1}$ Laboratório de Cultura de Tecidos, Departamento de Agricultura, Universidade Federal de \\ Lavras, Caixa Postal 3037, Campus da UFLA, 37200-000 Lavras, MG, Brazil \\ ${ }^{2}$ Laboratório de Ecofisiologia Vegetal, Departamento de Ciências Agrárias e Biológicas, Universidade Federal do \\ Espírito Santo, Rodovia Governador Mário Covas, Km 60, Bairro Litorâneo, 29932-540 São Mateus, ES, Brazil \\ ${ }^{3}$ Instituto de Desenvolvimento Rural, Universidade da Integração Internacional da Lusofonia \\ Afro-Brasileira, Av. da Abolição, 3, Centro, 62790-000 Redenção, CE, Brazil \\ ${ }^{4}$ Empresa de Pesquisa Agropecuária e Extensão Rural de Santa Catarina / EPAGRI-SC, \\ Rodovia Admar Gonzaga, 1347, Itacorubi, 88034-901 Florianópolis, SC, Brazil \\ ${ }^{5}$ Laboratório Central de Sementes, Departamento de Agricultura, Universidade Federal de \\ Lavras, Caixa Postal 3037, Campus da UFLA, 37200-000 Lavras, MG, Brazil
}

Manuscript received on July 6, 2017; accepted for publication on March 4, 2018

\begin{abstract}
The use of silicon in Billbergia zebrina cultivation in vitro is an alternative for optimizing micropropagation of this important ornamental plant species. The objective of the present study was to evaluate the growth and anatomical and physiological alterations in Billbergia zebrina (Herbert) Lindley plants as a function of different sources and concentrations of silicon during in vitro cultivation and acclimatization. The experimental design was completely randomized, with a double factorial arrangement and an additional control treatment $(2 \times 3+1)$. The first factor was relative to calcium silicate and sodium silicate added to the Murashige \& Skoog culture medium; the second factor was related to its concentrations, $0.5,1.0$, and $2.0 \mathrm{mg} \mathrm{L}^{-1}$. After 100 days, their growth, anatomical characteristics, level of silicon and chlorophyll content were evaluated. Growth characteristics were assessed after 60 days of acclimatization period. Plants absorbed more sodium silicate than calcium silicate. This source also stressed the plants impairing their growth, but the highest silicon absorption at $1 \mathrm{mg} \mathrm{L}^{-1}$ attenuated the stressful conditions. The supplementation of the culture medium with calcium silicate led to improved growth, anatomical, and physiological characteristics, which benefited the development of more resistant seedlings with better performance during acclimatization.
\end{abstract}

Key words: Bromeliad, micropropagation, plant anatomy, plant physiology, silicon.

\section{INTRODUCTION}

Tropical ornamental plants have an important role in tropical agriculture diversification and are highly

Correspondence to: Adalvan Daniel Martins

E-mail: adantins@yahoo.com.br valued in the international market (Ulisses et al. 2010). In particular, the bromeliads (Bromeliaceae) are very appreciated for their landscaping and ornamental characteristics, as they have colorful bracts and flowers that can last for several months, and leaves of great visual appeal (Pedroso et al. 
2010). However, it is still necessary to develop efficient seedling production techniques in order to produce with good quality and competitive commercial advantage.

Plant tissue culture technique can be successfully used to improve the vigor and vitality of the plants (Shahzad et al. 2017). It allows large scale seedling production for commercial cultivation, and may also be used in plant conservation programs, as many species belonging to the Atlantic Forest biome are threatened with extinction, including Billbergia zebrina (Herbert) Lindley of the Bromeliaceae family (Vesco et al. 2011).

However, the survival rates of micropropagated plants after they have been transferred to the ex vitro environment can be relatively low due to the in vitro culture conditions, thereby limiting the scale of propagation of some plant species (Hazarika 2006). This low survival rate is related to some in vitro environment characteristics, such as high relative air humidity, limited $\mathrm{CO}_{2}$ concentration, low irradiation, and high concentration of sugar in the culture medium. These conditions can affect the vigor of the tissues of such plants propagated in vitro and thus hinder their successful transfer to the ex vitro environment (Kozai et al. 2005, Park et al. 2011).

Furthermore, plant acclimatization represents a delicate phase in the production of micropropagated seedlings, not only due to water stress, photosynthesis, and nutrient absorption by the young plant, but also due to fungal and bacterial infections that can occur during this vulnerable stage (Tombolato and Costa 1998). To avoid this problem, it is necessary to develop research protocols that enable the production of in vitro seedlings with greater quality and more resistant to the stressful factors they are exposed to during acclimatization.

The use of silicate in the culture medium offers a possible tool to obtain bromeliads of greater quality that are resistant to acclimatization. This element contributes to the final quality of the plant, since its accumulation in the leaves confers plant protection, increases its photosynthetic capacity, reduces water loss and promotes its growth, and in general minimizes the biotic and abiotic stress factors that can affect the young plant (Epstein 1999).

Review articles about the use of silicon in plant tissue culture have demonstrated its efficacy (Sivanesan and Park 2014, Sahebi et al. 2016). The inclusion of this element in the culture medium in vitro has promoted the growth of explants (Braga et al. 2009, Soares et al. 2011, 2013), the induction of organogenesis and somatic embryogenesis (Abiri et al. 2017, Mathe et al. 2012), and has improved morphological, anatomical (Asmar etal.2013a), and physiological characteristics of the seedlings (Dias et al. 2017, Manivannan et al. 2017). Additionally, the use of silicon can increase plant tolerance to different biotic and abiotic stresses, such as salinity (Sivanesan and Jeong 2014, Soundararajan et al. 2015), drought (Watanabe et al. 2000, Liu et al. 2014), low temperatures (Duan et al. 2013), and metal toxicity (Prabagar et al. 2011).

Based on the efficacy of the tissue culture technique for plant propagation, the benefits derived from the use of silicate, and considering that the absorption of this nutrient by the plants is dependent on the chemical and structural nature of the compounds present in the culture medium, we proposed this research, which is a novelty about bromeliads micropropagation. Thus, the objectives of this study was to identify sources and concentration of silicates in the in vitro cultivation of Billbergia zebrina (Herbert) Lindley in order to develop plants that are more resistant to acclimatization.

\section{MATERIALS AND METHODS}

In vitro ESTABLISHMENT

The seeds of B. zebrina were disinfected and inoculated onto MS medium (Murashige and Skoog 
1962) for germination. For shoot multiplication, the internodal segments were inoculated onto MS stationary medium with $30 \mathrm{~g} \mathrm{~L}^{-1}$ of sucrose and 13.0 $\mu \mathrm{M}$ of 6-benzylaminopurine (BAP) (Martins et al. 2015a) for a period of 45 days. Nodal segments were inoculated in $250 \mathrm{~mL}$ glass flasks, each containing $50 \mathrm{~mL}$ of MS culture medium, with $5.5 \mathrm{~g} \mathrm{~L}^{-1}$ of agar, $30 \mathrm{~g} \mathrm{~L}^{-1}$ of sucrose, and a $\mathrm{pH}$ of 5.8. Calcium silicate $\left(\mathrm{CaSiO}_{3}\right)$ and sodium silicate $\left(\mathrm{Na}_{2} \mathrm{SiO}_{3}\right)$ were added to the MS medium at the concentrations of $0.5,1.0$, and $2.0 \mathrm{mg} \mathrm{L}^{-1}$. Basal MS medium with no silicate addition was considered as control treatment, thus establishing a factorial experiment with an additional treatment (i.e., $2 \times 3+1$ ). The culture medium was autoclaved at $121^{\circ} \mathrm{C}$ and $1 \mathrm{~atm}$ for $20 \mathrm{~min}$. After transferring the explants into the MS medium in a laminar flow chamber, the plants were maintained in a growth room with a 16 -h photoperiod, at $27 \pm 2{ }^{\circ} \mathrm{C}$, and a $32-\mu \mathrm{mol} \mathrm{m} \mathrm{m}^{-2} \mathrm{~s}^{-1}$ flux of photosynthetically active photons, for a period of 100 days.

\section{SILICON QUANTIFICATION}

\section{Colorimetric method}

Concentration of silicon was determined using the colorimetric method. For this analysis, three replicates formed of five whole plants from each treatment were randomly collected, washed, and dried in a forced-air ventilation oven, at $60{ }^{\circ} \mathrm{C}$ for $72 \mathrm{~h}$, until a constant weight was achieved; they were then ground separately to analyze the presence of the element. This analysis was performed according to the method proposed by Korndörfer et al. (2004).

\section{X-ray microanalysis}

Fragments of leaves were fixed on stubs with the aid of a double-sided adhesive tape of carbon and properly identified. Then they were kept for 24 $\mathrm{h}$ in a desiccator containing activated silica gel for dehydration. The samples were subsequently coated with carbon (Baltec CED 020) and analyzed using a scanning electron microscope (LEO EVO 40 XVP_Leo Electron Microscopy, Cambridge, UK) coupled to detection system of X-ray microanalysis: EDS X-Flash Detector 5010 (Bruker, Berlin, Germany), following the protocol described by Alves and Perina (2012).

\section{GROWTH CHARACTERISTICS}

Fifteen plants from each treatment were evaluated, divided into three replicates, and collected randomly. The roots were washed to remove the remaining culture medium. The number of roots (NR), root length (RL) in cm, number of sprouts (NS), number of leaves (NL), and root fresh weight (RFW), root dry weight (RDW), shoot fresh weight (SFW), and shoot dry weight (SDW) were determined in $\mathrm{mg}$. The dry weight of the plant material was obtained after drying in a $60^{\circ} \mathrm{C}$ oven until a constant weight was reached.

\section{LEAF ANATOMY ANALYSIS}

Three plants from each treatment were randomly collected and fixed in 70\% ethanol. Transversal and paradermal sections were obtained from the medial region of the foliar limb of the first fully expanded leaf. The sections were clarified in 3\% (v/v) sodium hypochlorite solution and later stained using a 7:3 solution of Astra Blue (0.1\%) and safranin (1\%) (Bukatsch 1972); 50\% glycerin (v/v) was used to assemble the slides.

The sections obtained were visualized using an optical light microscope (Zeiss MicroImaging GmbH Scope.A1, Göttingen, Germany) coupled to a digital camera (Canon A630, Tokyo, Japan) for image capture. The photomicrographs generated were used to measure the anatomical structures with the help of the UTHSCSA-Imagetool ${ }^{\circledR}$ software. The characteristics measured were the following: stomatal density (no. $\mathrm{cm}^{-2}$ ), thicknesses 
of the adaxial and abaxial leaf sides of the epidermis $(\mu \mathrm{m})$, thicknesses of the hydrenchyma and the chlorenchyma $(\mu \mathrm{m})$, and xylem vessel diameter $(\mu \mathrm{m})$.

\section{LEVELS OF CHLOROPHYLL $a$ AND $b$}

Levels of photosynthetic pigments in B. zebrina leaves were determined in the Laboratory of Plant Products, in the Department of Food Science of UFLA. Nine plants per treatment were used for this purpose, corresponding to three plants per repeat. A known quantity of fresh plant material $( \pm$ $0.5 \mathrm{~g}$ ) was used in the analysis and later ground in $10 \mathrm{ml}$ of $80 \%$ acetone to extract the chlorophyll. The solution was filtered and analyzed in a spectrophotometer at the wavelengths of 470,645 , 652 , and $663 \mathrm{~nm}$, according to the methodology by Engel and Poggiane (1991). The equations proposed by Li et al. (2013) were used to calculate the levels of chlorophylls $a$ and $b$.

\section{ACCLIMATIZATION}

After 100 days of culture in vitro, 15 plants from each treatment were transferred onto greenhouse trays. These plants were previously washed in order to remove the culture medium from the roots, thus avoiding the development of any fungus that may hinder the growth of the seedlings. Tropstrato ${ }^{\circledR}$ was the substrate used during acclimatization. The plants were maintained in the greenhouse with $70 \%$ shading for 60 days, and then the growth characteristics were analyzed to quantify NR, RL, NS, NL, RFW, RDW, SFW, and SDW.

\section{EXPERIMENTAL DESIGN AND STATISTICAL ANALYSIS}

A completely randomized experimental design was adopted, with a double factorial arrangement with and additional control treatment $(2 \times 3+$ 1). Therefore, the data collected were submitted to analysis of variance (ANOVA) and the means were sorted using Tukey's multiple range test at $5 \%$ of probability. The comparison between the treatments with silicon and the control was performed using the Dunnett's multiple range test at $5 \%$ of probability.

\section{RESULTS}

\section{SILICON CONTENT}

The levels of silicon ( $\mathrm{Si}$ ) obtained using both methods of quantification were comparable (Figure 1a). There was a significant interaction between the sources and concentration of silicate in the determination of the level of silicon present in the plants. B. zebrina was unable to absorb and incorporate silicon in its biomass when the source was calcium silicate, presenting values similar to those observed in the control treatment. Conversely, using sodium silicate in the cultivation of $B$. zebrina allowed higher absorption of silicon by the plants. The use of 1.0 and $2.0 \mathrm{mg} \mathrm{L}^{-1}$ sodium silicate resulted in higher levels of $\mathrm{Si}$ in both methods, with $92 \%$ and $75 \%$ more silicon detected when compared with the control treatment (by the colorimetric method), respectively. Evaluation of the levels of Si by the X-ray method was not sufficiently sensitive to detect the presence of silicon on the control treatment (Figure 1a, b).

GROWTH ANALYSIS - In vitro

The NR, RL, NS, RFW, RDW, SFW and SDW presented a significant interaction between the source and concentration of silicate used. For the number of leaves (NL), only the isolated factors were statistically significant. No significant difference was observed in NR among the concentrations used in the treatment with calcium silicate, presenting a lower amount of roots when compared with the other source tested, sodium silicate (Figure 2a). In addition, for the calcium silicate source, only the treatment with $1.0 \mathrm{mg} \mathrm{L}^{-1}$ was different from the control. Using $2.0 \mathrm{mg} \mathrm{L}^{-1}$ sodium silicate resulted in an increase of $40 \%$ on 
(a)

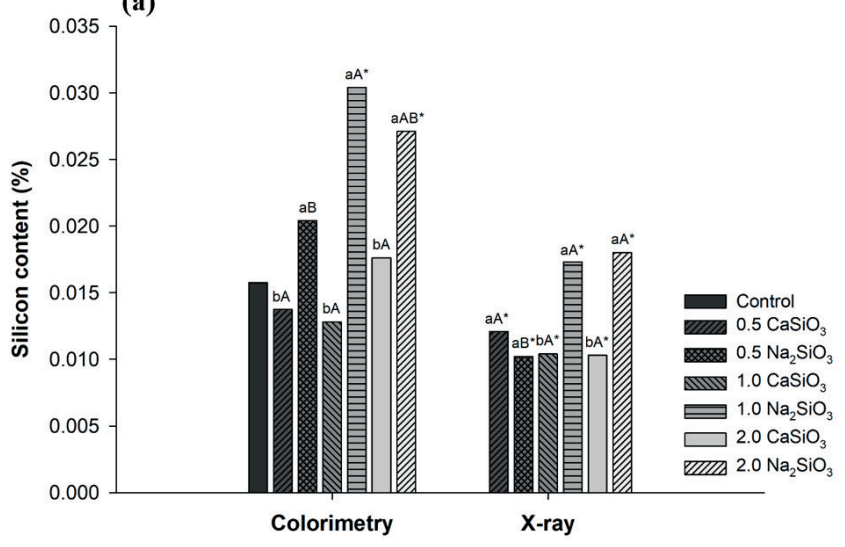

(b)

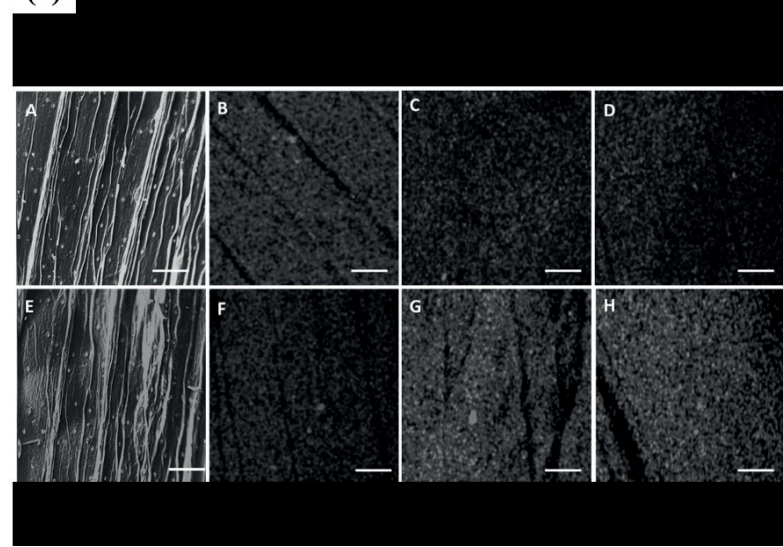

Figure 1 - (a) Silicon content (\%) by colorimetric method and X-Ray microanalysis and (b) silicon mapping at the abaxial epidermis in plants of B. zebrina as a function of different sources and concentrations $\left(\mathrm{mg} \mathrm{L}^{-1}\right)$ of silicates after 100 days of in vitro growth. (a) means followed by '*' are different from the control by Dunnet's multiple range test at 5\% probability; lowercase letters refer to the unfolding of the sources within each concentration; the means with distinct lowercase letters are different by Tukey's multiple range test at 5\% probability. Capital letters refer to the unfolding of concentrations within each source; the means with distinct capital letters are different by Tukey's multiple range test at $5 \%$ probability. (b): (A) control; (B) $0.5 \mathrm{mg} \mathrm{L}^{-1} \mathrm{CaSiO}_{3}$; (C) 1 $\mathrm{mg} \mathrm{L}^{-1} \mathrm{CaSiO}_{3}$; (D) $2 \mathrm{mg} \mathrm{L}^{-1} \mathrm{CaSiO}_{3}$; (E) control; (F) $0.5 \mathrm{mg} \mathrm{L}^{-1} \mathrm{Na}_{2} \mathrm{SiO}_{3}$; (G) $1 \mathrm{mg} \mathrm{L} \mathrm{Na}_{2} \mathrm{SiO}_{3}$; (H) $2 \mathrm{mg} \mathrm{L}^{-1} \mathrm{Na}_{2} \mathrm{SiO}_{3}$. $\mathrm{Bar}_{100 \mu \mathrm{m}}$.

the NR when compared to the control treatment. RL was greater at $2.0 \mathrm{mg} \mathrm{L}^{-1}$ calcium silicate, differing from the other concentrations tested for this source (Figure 2a). However, all the concentrations were enough to promote greater root growth compared to the control treatment. Sodium silicate at $1.0 \mathrm{mg}$ $\mathrm{L}^{-1}$ promoted higher RL compared to the other two concentrations of this source; it was also the only treatment that differed from the control.

The highest NS was obtained at $2.0 \mathrm{mg}$ $\mathrm{L}^{-1}$ sodium silicate (Figure $2 \mathrm{a}$ ); it was the only treatment statistically different from the control. Regarding calcium silicate, there was no significant difference detected between the concentrations. Sodium silicate at $1.0 \mathrm{mg} \mathrm{L}^{-1}$ showed the highest $\mathrm{NL}$ among all concentrations (Figure 2a). However, none of the treatments differed from the control. Higher weight values were obtained both for RFW and RDW, as well as SFW, when $2.0 \mathrm{mg} \mathrm{L}^{-1}$ calcium silicate was used (Figure $2 \mathrm{~b}$ ), which did not differ from the treatment with $1.0 \mathrm{mg} \mathrm{L}^{-1}$ to RDW and SFW. Both concentrations were superior to the control treatment for these characteristics.
Sodium silicate at $1.0 \mathrm{mg} \mathrm{L}^{-1}$ showed higher RFW, RDW, SFW and SDW and differed from the control (Figure 2b).

\section{LEAF ANATOMY ANALYSIS}

Silicate sources and concentrations had significant effect on the leaf stomatal density, thickness of the adaxial epidermis, hydrenchyma and chlorenchyma and diameter of xylem vessels. The differences can be observed by the paradermal section of the leaves (Figure 3a). Higher number of stomata were observed at $2.0 \mathrm{mg} \mathrm{L}^{-1}$ calcium silicate, increasing up to $30 \%$ when compared to the control treatment. In contrast, the number of stomata reduced when concentrations above $1.0 \mathrm{mg} \mathrm{L}^{-1}$ sodium silicate were used, leading to $50 \%$ lower stomatal density than observed in the control treatment (Figure 3c). Adaxial and abaxial epidermis can be visualized by the cross section of the leaves (Figure $3 b$ ). The use of sodium silicate at 1.0 and $2.0 \mathrm{mg} \mathrm{L}^{-1}$ resulted in thicker adaxial epidermis when compared to the other treatment levels. Regarding abaxial epidermis thickness, only the sources of silicon used were 

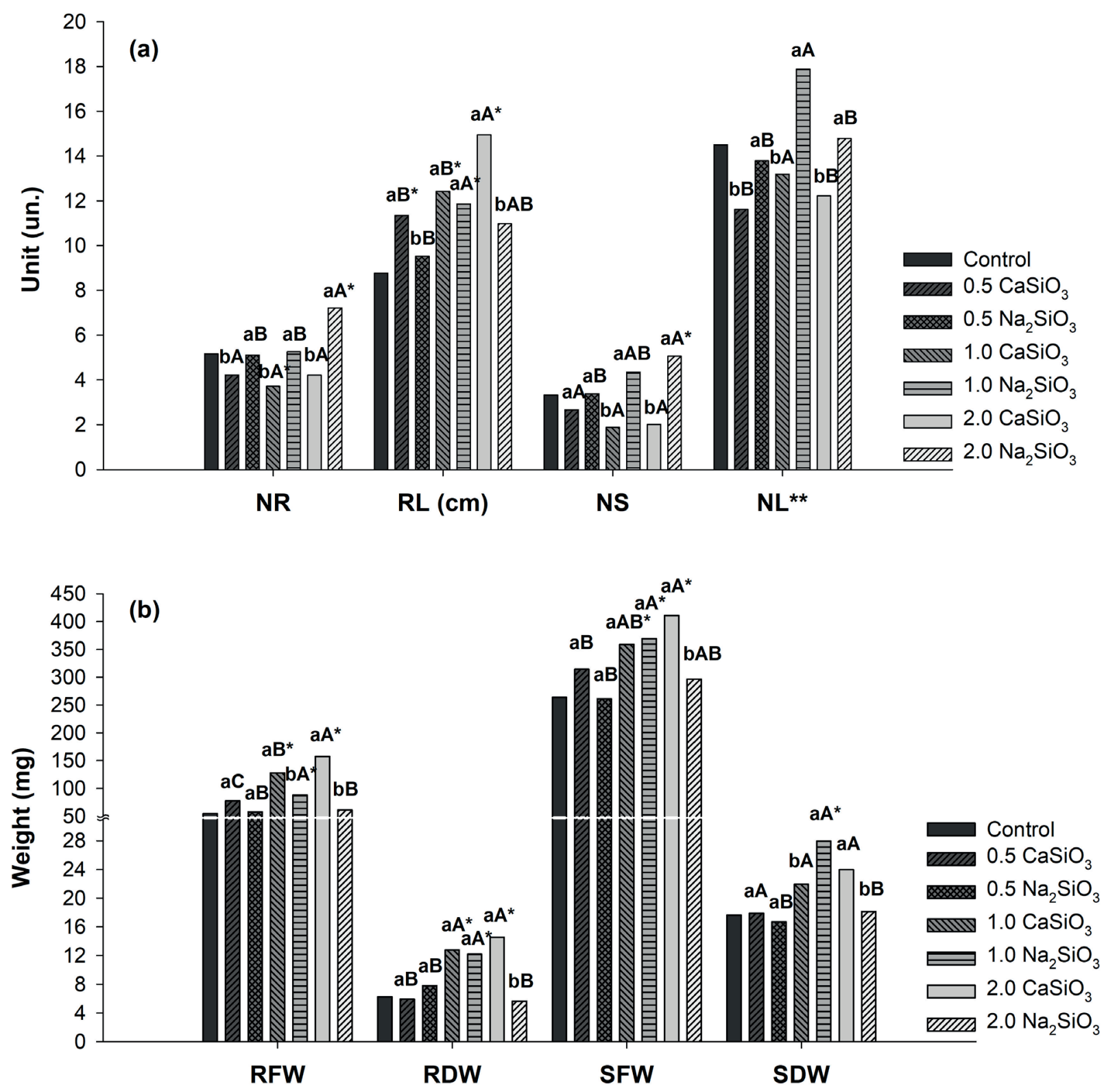

Figure 2 - Growth analysis in plants of B. zebrina as a function of different sources and concentrations ( $\left.\mathrm{mg} \mathrm{L}^{-1}\right)$ of silicates after 100 day of in vitro growth. (a) Number of roots (NR), root length (RL) in cm, number of shoots (NS) and number of leaves (NL); (b) Root fresh weight (RFW), root dry weight (RDW), shoot fresh weight (SFW) and shoot dry weight (SDW) in mg. Means followed by '*' are different from the control by Dunnet's multiple range test at $5 \%$ probability; lowercase letters refer to the unfolding of the sources within each concentration, the means with distinct lowercase letters are different by Tukey's multiple range test at $5 \%$ probability; Capital letters refer to the unfolding of concentrations within each source, the means with distinct capital letters are different by Tukey's multiple range test at $5 \%$ probability. '**' Indicate no significant statistical interaction between the sources and concentrations. 


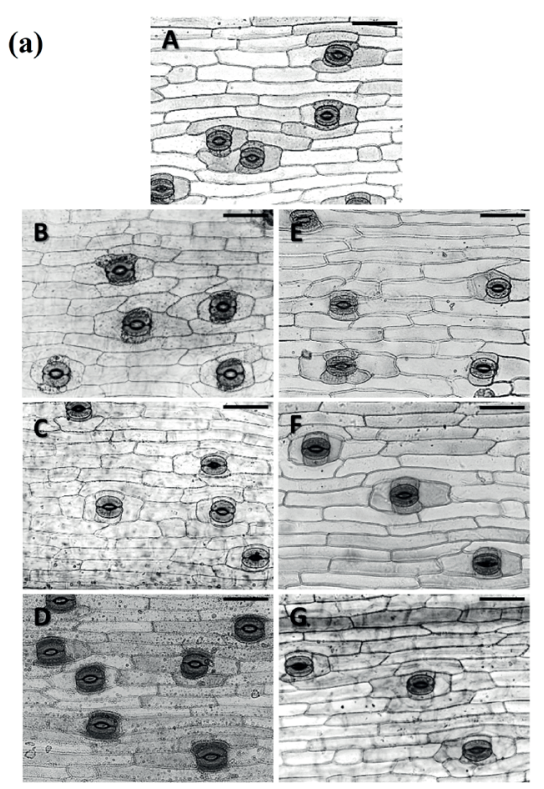

(c)

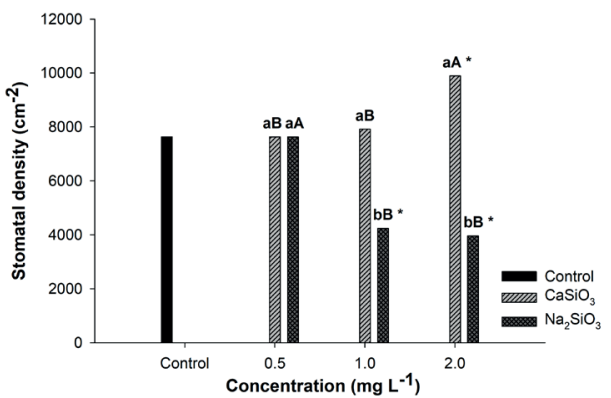

(e)

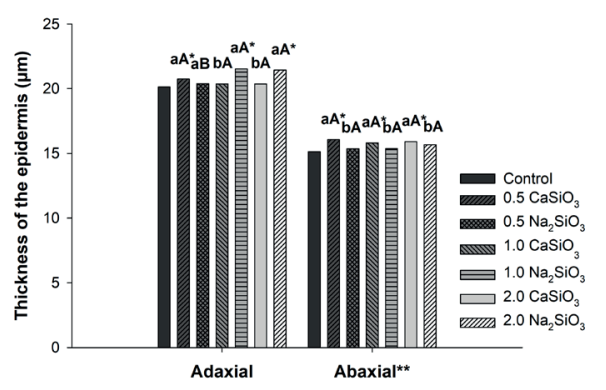

(b)
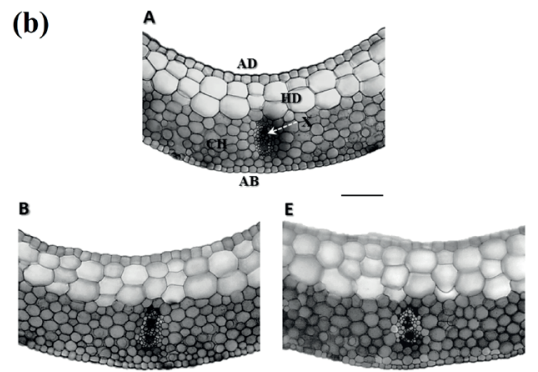

c
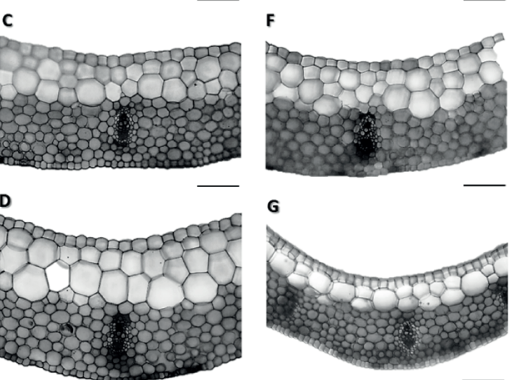

(d)

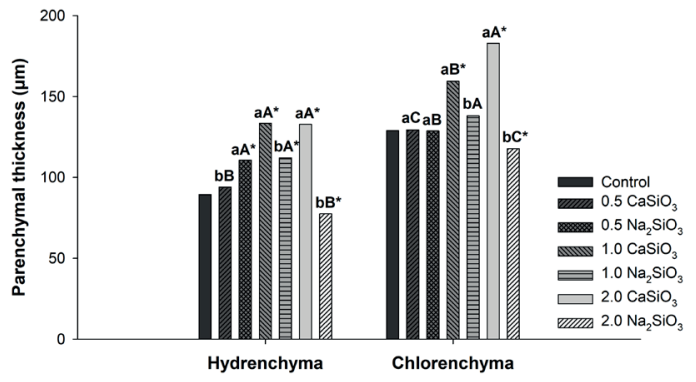

(f)

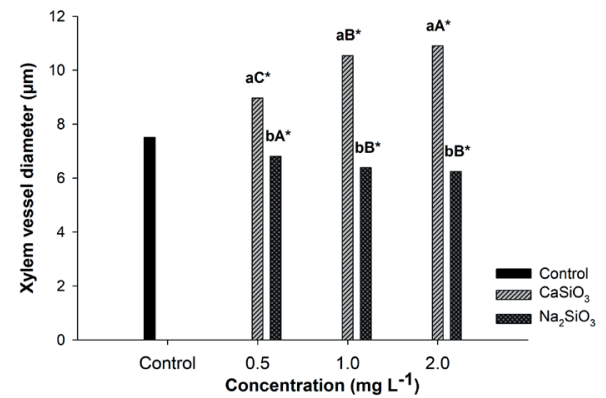

Figure 3 - Paradermal (a), cross sections (b), stomatal density (c), thickness of the epidermis (d), parenchymal thickness (e) and xylem vessel diameter (f) of B. zebrina leaves as a function of different sources and concentrations ( $\mathrm{mg} \mathrm{L}^{-1}$ ) of silicates after 100 day of in vitro growth. (a-b): (A) Control; (B-D) 0.5, 1.0 and 2.0 $\mathrm{CaSiO}_{3} \mathrm{mg} \mathrm{L}^{-1}$, respectively; (E-G) 0.5, 1.0 and $2.0 \mathrm{Na}_{2} \mathrm{SiO}_{3} \mathrm{mg} \mathrm{L}^{-1}$, respectively. Adaxial epidermis (AD), abaxial epidermis (AB), hydrenchyma (HD), chlorenchyma (CH) and xylem (X). (c-f): means followed by ' $*$ ' are different from the control by Dunnet's multiple range test at 5\% probability; lowercase letters refer to the unfolding of the sources within each concentration; the means with distinct lowercase letters are different by Tukey's multiple range test at $5 \%$ probability. Capital letters refer to the unfolding of concentrations within each source; the means with distinct capital letters are different by Tukey's multiple range test at 5\% probability. ' $* *$ ’ Indicate no significant statistical interaction between the sources and concentrations. Bars $50 \mu \mathrm{m}$ (a) and $100 \mu \mathrm{m}$ (b). 
significant, with calcium silicate resulting in higher thickness values for this epidermis (Figure 3e).

The cross section of the leaves at the Figure $3 \mathrm{~b}$ shows both parenchyma structures. Near 50\% increase in hydrenchyma thickness was observed when either 1.0 or $2.0 \mathrm{mg} \mathrm{L}^{-1}$ calcium silicate were used. Sodium silicate at 0.5 and $1.0 \mathrm{mg} \mathrm{L}^{-1}$ resulted in approximately $25 \%$ increase in the hydrenchyma thickness compared with the control. However, high concentration of this compound impaired the development of the hydrenchyma; thus, 2.0 $\mathrm{mg} \mathrm{L}^{-1}$ sodium silicate resulted in lower thickness when compared with the control treatment. All treatments were statistically different from the control, except $0.5 \mathrm{mg} \mathrm{L}^{-1}$ calcium silicate (Figure $3 \mathrm{~d})$. Chlorenchyma thickness increased with the use of 1.0 and $2.0 \mathrm{mg} \mathrm{L}^{-1}$ calcium silicate. The highest concentration resulted in greater thickness for this tissue, with an increase of approximately $42 \%$ compared to the control. However, a reduction in chlorenchyma thickness was observed for all sodium silicate concentrations tested when compared to the control. The lowest chlorenchyma thickness was observed at $2.0 \mathrm{mg} \mathrm{L}^{-1}$ sodium silicate concentration (Figure 3d).

The diameter of the xylem vessels increased as the concentrations of calcium silicate increased. As such, the greatest diameter was observed at the highest concentration. The opposite effect was observed with the use of sodium silicate, for which a xylem diameter $17 \%$ lower than the control treatment was observed. All treatments were statistically different from the control (Figure 3f).

\section{CHLOROPHYLL CONTENT}

The interaction between the factors was not significant with respect to the level of chlorophyll $a$. However, the factors in isolation significantly influenced this variable. The highest level of chlorophyll $a$ was observed when $1.0 \mathrm{mg} \mathrm{L}^{-1}$ calcium silicate was added to the medium, but no difference between 0.5 and $2.0 \mathrm{mg} \mathrm{L}^{-1}$ concentrations was noticed. All treatments differed statistically from the control (Figure 4). Significant interaction was detected between the sources and concentrations used to chlorophyll $b$ content. The use of calcium silicate resulted in higher levels of chlorophyll $b$ when compared with sodium silicate. Besides, at all calcium silicate concentrations tested, the levels of this chlorophyll type were statistically different from the control. The use of sodium silicate resulted in higher level of chlorophyll $b$ only at $1.0 \mathrm{mg} \mathrm{L}^{-1}$ concentration when compared with the control treatment (Figure 4).

\section{GROWTH ANALYSIS - ACCLIMATIZATION}

The plants behaved similarly to what was observed in vitro for some characteristics during acclimatization. There was significant interaction between the sources and concentrations of silicates for NR, RL, RFW, RDW, SFW and SDW. Different concentrations of calcium silicate did not interfere on the NR and RL, yet this source also resulted in higher NR and lower RL compared to sodium silicate, especially at 1.0

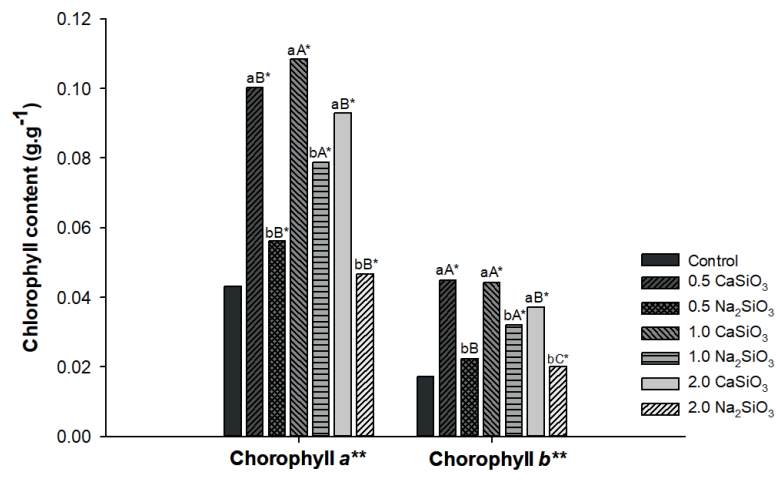

Figure 4 - Chlorophyll $a$ and $b$ content $\left(\mathrm{g} \mathrm{g}^{-1}\right)$ of B. zebrina leaves as a function of different sources and concentrations $\left(\mathrm{mg} \mathrm{L}^{-1}\right)$ of silicates after 100 days of in vitro growth. Means followed by '*' are different from the control by Dunnet's multiple range test at $5 \%$ probability; lowercase letters refer to the unfolding of the sources within each concentration, the means with distinct lowercase letters are different by Tukey's multiple range test at 5\% probability; Capital letters refer to the unfolding of concentrations within each source, the means with distinct capital letters are different by Tukey's multiple range test at $5 \%$ probability. ' $* *$ ' Indicate no significant statistical interaction between the sources and concentrations. 

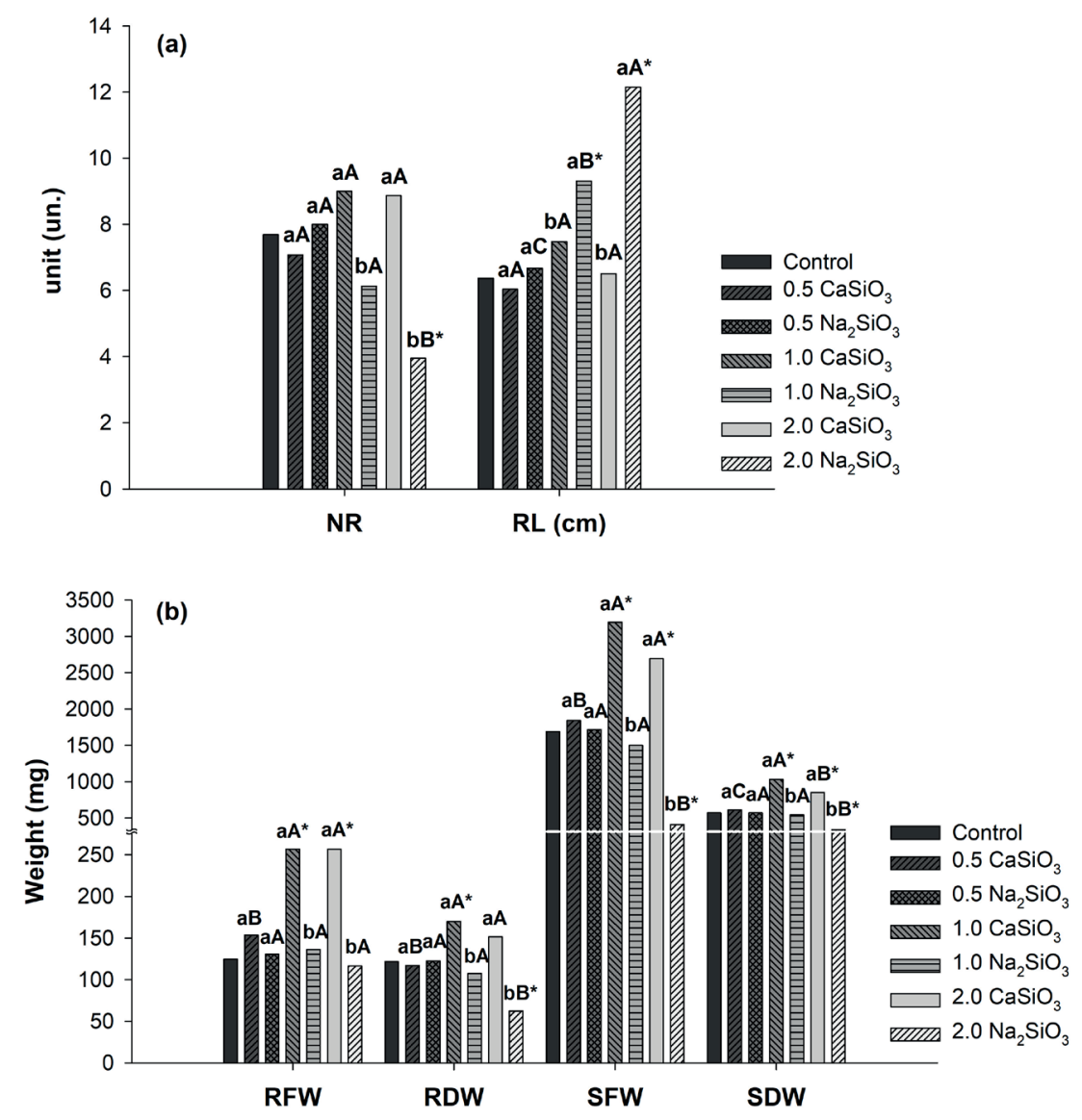

Figure 5 - Growth analysis in plants of B. zebrina as a function of different sources and concentrations ( $\mathrm{mg} \mathrm{L}^{-1}$ ) of silicates after 60 days of ex vitro growth. (a) Number of roots (NR), root length (RL) in cm; (b) Root fresh weight (RFW), root dry weight (RDW), shoot fresh weight (SFW) and shoot dry weight (SDW) in mg. Means followed by '*' are different from the control by Dunnet's multiple range test at 5\% probability; lowercase letters refer to the unfolding of the sources within each concentration. The means with distinct lowercase letters are different by Tukey's multiple range test at 5\% probability; capital letters refer to the unfolding of concentrations within each source, the means with distinct capital letters are different by Tukey's multiple range test at $5 \%$ probability.

and $2.0 \mathrm{mg} \mathrm{L}^{-1}$ (Figure 5a). The NR was significantly lower than the control at $2.0 \mathrm{mg} \mathrm{L}^{-1}$ calcium silicate while RL was higher at the concentrations 1.0 and $2.0 \mathrm{mg} \mathrm{L}^{-1}$ sodium silicate. Regarding NS and NL, neither an interaction between the factors nor any statistical difference within each factor was detected (Figure 5a).

The lowest values for RFW and RDW were obtained with the use of sodium silicate at 1.0 and $2.0 \mathrm{mg} \mathrm{L}^{-1}$ (Figure 5b). These same concentrations led to higher RFW and RDW with calcium silicate source, increasing approximately $94 \%$ and $32 \%$ above the control, respectively. Regarding the RDW, only at $1.0 \mathrm{mg} \mathrm{L}^{-1}$ calcium silicate there was a significant positive difference compared with the control, whereas a significant negative difference was observed with sodium silicate at the concentration $2.0 \mathrm{mg} \mathrm{L}^{-1}$ (Figure 5b). SFW and SDW were higher in the treatment with calcium silicate at 1.0 and $2.0 \mathrm{mg} \mathrm{L}^{-1}$ than the sodium silicate source and the control. SDW increased $81 \%$ above the control at $1.0 \mathrm{mg} \mathrm{L}^{-1}$ calcium silicate, whereas $2.0 \mathrm{mg} \mathrm{L}^{-1}$ sodium silicate reduced $40 \%$ (Figure 5b). An image of the plants at the end of the acclimatization period can be seen in Figure 6 . 


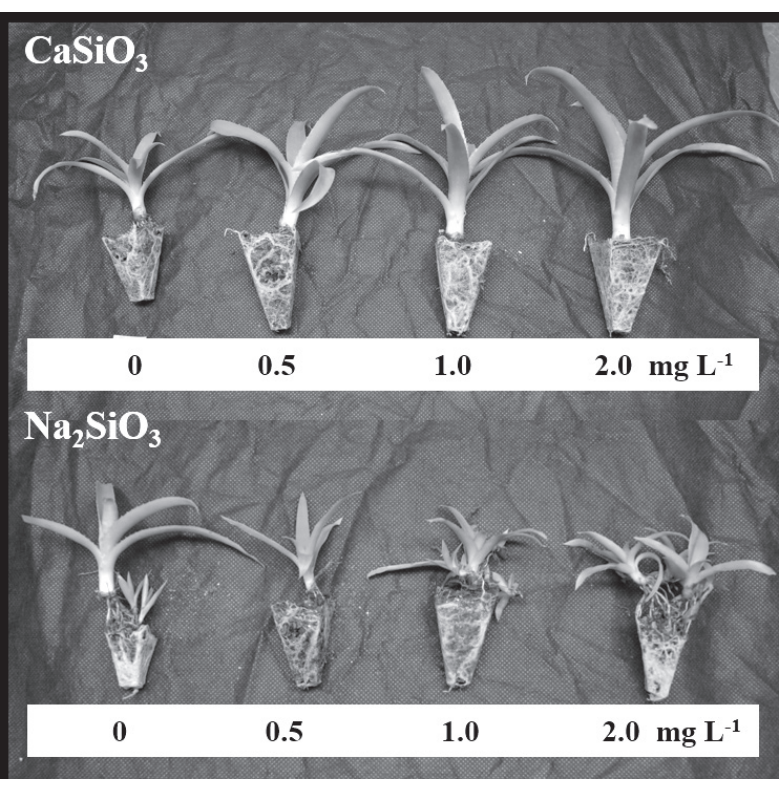

Figure 6 - B. zebrina plants after 60 days of ex vitro growth (acclimatization) in response to sources and concentrations $\left(\mathrm{mg} \mathrm{L}^{-1}\right)$ of silicates during the in vitro culture.

\section{DISCUSSION}

The greater Si absorption derived from sodium silicate source compared to calcium silicate may be explained by the dynamics of nutrient absorption. According to Malavolta et al. (1997), the absorption of a certain element is influenced by the presence of another. Possibly, the differential concentrations of $\mathrm{Ca}^{2+}$ and $\mathrm{Na}^{+}$ions from the silicates source had an influence on the absorption of Si. In addition, $\mathrm{Si}$ may have been absorbed by the plant as a defense mechanism against the possible salt stress generated by $\mathrm{Na}^{+}$ions, in that silicon functions effectively to mitigate different types of stress in plants (Zhu and Gong 2014). Besides, $\mathrm{Na}^{+}$ions can be absorbed faster than $\mathrm{Ca}^{2+}$ ions by the plants, which may have contributed for the highest Si absorption with sodium silicate (Schaedle 1990, Faquin 2005).

Asmar et al. (2013b) verified greater absorption of calcium silicate in relation to sodium and potassium silicates in 'Grand Naine' banana plants. However, higher calcium and sodium silicates was absorbed in micropropagated 'Maçã' banana plants when compared to potassium silicate source (Asmar et al. 2011). This difference shows that the absorption of silicon depends not only on the source used but also on the species and variety of plant studied.

Regarding the difference observed on the silicon levels between the colorimetric method and the X-ray microanalysis, this result could arise from the unequal accuracy of the two methods. X-Ray Microanalysis technique is a qualitative and quantitative analysis of samples, which allows measuring almost all the elements with physiological, cellular and subcellular interest in plants (Frey 2007). The results obtained by Reidinger et al. (2012), who compared the data from silicon analyses by X-rays and other methods, demonstrated a Pearson's correlation coefficient of just 0.644 between the X-rays and the colorimetric methods, suggesting that these techniques can show different results. Dias et al. (2017) detected 0.23 to $0.40 \%$ of $\mathrm{Si}$ in anthurium leaves cultivated in MS medium with sodium silicate. There have been no reports in the literature regarding the deposition of Si in B. zebrine.

Generally, the use of calcium silicate led to a better performance of $B$. zebrina plants in vitro in terms of its growth traits. However, based on the Si analysis, in which the absorption of this element was compromised, we suggest that the improvement obtained using this source was due to the higher availability of calcium to the plants, as this element is very important for plant development, particularly in bromeliads. Calcium plays an important role in processes related to the maintenance of the structural and functional integrity of plant cell membranes, stabilizes cell wall structures, controls ions selectivity and transport, and also regulates ion-exchange behavior as well as cell wall enzyme activity (Radi and Karimi 2012). Aranda-Peres et al. (2009) highlighted the various benefits of supplementing MS medium with calcium for the micropropagation of Vriesea friburgensis, $V$. hieroglyphica, and $V$. 
unilateralis, placing this macronutrient on the list of key elements for bromeliads.

Conversely, the higher silicon absorption when using the source sodium silicate, especially at the concentration of $1.0 \mathrm{mg} \mathrm{L}^{-1}$, shows that silicon can favor plant propagation, in light of the greater accumulation of mass in the aerial part observed in this treatment. Sivanesan and Park (2014) pointed out that silicon is beneficial for the plants during the in vitro culture, and it can also improve the productivity of various plants. Moreover, this nutrient may minimize several types of stress, including nutritional imbalance. Asmar et al. (2013b) obtained longer root length with sodium silicate compared to calcium silicate in 'Grand Naine' banana plants. Pasqual et al. (2011) and Soares et al. (2013) verified that the use of different silicon sources in vitro optimized orchid seedlings micropropagation. All these results show that the response of the plants to silicon depends on its source, concentration and the plant species.

The results for the anatomical modifications in the present work can be discussed in two different ways. First, from the plausible view that calcium silicate improved the plants anatomical characteristics due to the transport of $\mathrm{Ca}^{2+}$ to the inside of the plant. Second, considering the alteration in the anatomy in response to sodium silicate as an attempt to protect those plants against the possible salt stress generated by the increase in the concentration of $\mathrm{Na}^{+}$ions in the culture medium (with silicon being the main attenuating agent against this stress).

The increase in the number of stomata due to the use of calcium silicate may contribute for a better transpiration control, which can lead to higher adaptability to the ex vitro environment (Dias et al. 2014). Calcium is a critical component of the cell wall, involved on the permeability of the cell membrane; it also favors plant transpiration (Raven et al. 2007). In contrast, the reduction in the number of stomata can mitigate water loss via transpiration in response to the stress caused by the sodium silicate.

Thickness of the adaxial epidermis was larger with the use of sodium silicate, which may be related to the formation of a physical barrier against water loss due to silicon deposition in the cells (Korndörfer 2006). The thicker abaxial epidermis found when calcium silicate was used may be related to the structural role of calcium (Prado 2008 ), once it can provide greater protection to the stomatal cells - in the case of B. zebrine these are concentrated on the abaxial side of the leaf, which helps with the regulation of transpiration. A greater abaxial epidermal thickness was also obtained in the cultivation of 'Maçã' banana plants in vitro, when using calcium silicate in comparison to sodium and potassium silicate sources (Asmar et al. 2013a).

The higher thickness of the hydrenchyma and chlorenchyma found when calcium silicate was used are associated to the greater water storage capacity (Martins et al. 2014) and the maintenance of the water status of the cells (Martins et al. $2015 b$ ) for the first parameter and to the greater capacity to perform photosynthesis for the second, because more developed chlorenchyma may be correlated with higher photosynthetic rates (Freschi et al. 2010). On the other hand, the reduction in the thickness of these parenchyma at high concentration of sodium silicate may have been influenced by the high concentration of $\mathrm{Na}^{+}$ions, making it difficult to absorb water and affecting growth (Parvaiz and Satyawati 2008). Asmar et al. (2013a) obtained thicker palisade parenchyma in banana 'Maçã' cultivated in vitro with the addition of calcium silicate to the culture medium, which also resulted in higher photosynthetic rates compared to other silicon sources.

The xylem vessels diameter can influence the ability of plants to translocate nutrients from the culture medium to the shoot apex. The higher availability of calcium in the medium with calcium 
silicate may have resulted in larger xylem vessels diameters, since this nutrient may help maintain the integrity of the plasma membrane of the cells, allowing greater turgor pressure inside the vessels and increasing the retention of nutrients (ArandaPeres et al. 2009). Furthermore, larger vessel diameters are related to increased water conductivity (Rodríguez-Gamir et al. 2010). Nevertheless, higher concentration of sodium silicate led to the reduction of the xylem vessels diameter, possibly as an attempt to reduce the translocation of $\mathrm{Na}^{+}$ ions from the root to the shoot of the plants, which is carried out exclusively via xylem through the transpiratory flow (Tester and Davenport 2003).

The chlorophyll content is related to the ability of plants to photosynthesize. Chlorophyll $a$ is the pigment used to perform the photochemistry phase, while chlorophyll $b$ has influence on the light absorption and on the radiant energy transfer to the reaction centers (Streit et al. 2005). Calcium silicate led to higher content of chlorophyll $a$ and $b$, this can be related to the greater thickness of the chlorenchyma and, possibly, to the higher number of stomata which increases the capacity of plants to capture $\mathrm{CO}_{2}$, stimulating the production of chlorophyll within the chlorenchyma (Asmar et al. 2013b).

The higher chlorophyll $b$ content found increases the absorption of energy from the radiation; it also increases the photosynthetic potential of these plants and their adaptability to the acclimatization. Although chlorophyll content was lower when the plants were exposed to sodium silicate, the presence of this source increased the chlorophyll content in the plants, mainly at $1 \mathrm{mg}$ $\mathrm{L}^{-1}$. Braga et al. (2009) also reported an increase in chlorophyll content and leaf weight in strawberry cultivated in vitro in the presence of sodium silicate compared to other silicate sources.

The behavior of B. zebrina plants observed in vitro in the presence of different sources and concentrations of silicate in this research had a great influence on the performance of the plants during acclimatization. The plants cultivated in vitro with the addition of calcium silicate to the culture medium were noticeably superior in relation to those cultivated with the use of sodium silicate, which in turn were inferior even when compared to the control treatment. The better performance of the plants in the presence of calcium silicate was possibly due to an increase in the concentration of calcium in the plant tissues, once the absorption of silicon from this source was limited. Likely, sodium silicate source caused stress to the plants due to the elevated concentration of $\mathrm{Na}^{+}$ions present in the media culture, thus hindering the ex vitro development of the plants.

The magnification of plant anatomical structures - namely the increased number of stomata, greater thickness of the abaxial epidermis, thicker hydrenchyma and chlorenchyma - in addition to the higher chlorophyll content present in the plants treated with calcium silicate, mainly at 1.0 and $2.0 \mathrm{mg} \mathrm{L}^{-1}$, led to the optimization of the seedlings production of $B$. zebrina during the acclimatization, attesting the importance and practical application of the present study.

\section{CONCLUSIONS}

Calcium silicate promotes better performance of $B$. zebrina plants in vitro and mainly during the acclimatization, especially at $1.0 \mathrm{mg} \mathrm{L}^{-1}$, therefore recommended for micropropagation of this species. Despite the stress caused by the use of sodium silicate in the in vitro cultivation, this silicate at 1.0 $\mathrm{mg} \mathrm{L}^{-1}$ mitigates the stress generated in the plants, attesting to the role of silicon on the protection of plants under stressful conditions.

\section{ACKNOWLEDGMENTS}

The authors sincerely acknowledge the Universidade Federal de Lavras, the Electron Microscopy Laboratory (LME), the Coordenação de Aperfeiçoamento de Pessoal de Nível Superior (CAPES), the Conselho Nacional de 
Desenvolvimento Científico e Tecnológico (CNPq) and the Fundação de Amparo à Pesquisa do Estado de Minas Gerais (FAPEMIG) for the assistance, financial support of the project and for the student fellowships.

\section{REFERENCES}

ABIRI R, MAZIAH M, SHAHARUDDIN NA, YUSOF ZNB, ATABAKI N, HANAFI MM, SAHEBI M, AZIZI P, KALHORI N AND VALDIANI A. 2017. Enhancing somatic embryogenesis of Malaysian rice cultivar MR219 using adjuvant materials in a high-efficiency protocol. Int J Environ Sci Technol 14: 1091-1108.

ALVES E AND PERINA FJ. 2012. Apostila do curso introdutório à microscopia eletrônica de varredura e microanálise de raios-X. UFLA/FAEPE, Lavras, 63 p.

ARANDA-PERES AN, PERES LEP, HIGASHI EN AND MARTINELLI AP. 2009. Adjustment of Mineral Elements in the Culture Medium for the Micropropagation of Three Vriesea Bromeliads from the Brazilian Atlantic Forest: The Importance of Calcium. HortScience 44: 106-112.

ASMAR SA, CASTRO EM, PASQUAL M, PEREIRA FJ AND SOARES JDR. 2013a. Changes in leaf anatomy and photosynthesis of micropropagated banana plantlets under different silicon sources. Sci Hort 161: 328-332.

ASMAR SA, PASQUAL M, ARAUJO AG, SILVA RAL, RODRIGUES FA AND PIO LAS. 2013b. Características morfofisiológicas de bananeiras 'Grande Naine' aclimatizadas em resposta a utilização de silício in vitro. Semin: Cien Agrar 34: 73-82.

ASMAR SA, PASQUAL M, RODRIGUES FA, ARAUJO AG, PIO LAS AND SILVA SO. 2011. Fontes de silício no desenvolvimento de plântulas de bananeira 'Maçã' micropropagadas. Cienc Rural 41: 1127-1131.

BRAGA FT, NUNES CF, FAVERO AC, PASQUAL M, CARVALHO JG AND CASTRO EM. 2009. Características anatômicas de mudas de morangueiro micropropagadas com diferentes fontes de silício. Pesq Agropec Bras 44: 128-132.

BUKATSCH F. 1972. Bermerkungen zur Doppelfärbung Astrablau-Safranin. Mikrokosmos, 255 p.

DIAS GMG, SOARES JDR, RIBEIRO SF, MARTINS AD, PASQUAL M AND ALVES E. 2017. Morphological and physiological characteristics in vitro anthurium plantlets exposed to silicon. Crop Breed Appl Biotechnol 17: 18-24.

DIAS MC, CORREIA C, MOUTINHO-PEREIRA J, OLIVEIRA H AND SANTOS C. 2014. Study of the effects of foliar application of ABA during acclimatization. Plant Cell Tissue Organ Cult 117: 213-224.

DUAN X, TANG M AND WANG W. 2013. Effects of silicon on physiology and biochemistry of Dendrobium moniliforme plantlets under cold stress. Agric Biotechnol 2: 18-21.
ENGEL VLAND POGGIANE F. 1991. Estudo da concentração de clorofila nas folhas e seu espectro de absorção de luz em função do sombreamento em mudas de quatro espécies florestais nativas. Braz J Plant Physiol 3: 39-45.

EPSTEIN E. 1999. Silicon. Annu Rev Plant Physiol Plant Mol Biol 50: 641-664.

FAQUIN V. 2005. Nutrição Mineral de Plantas. Lavras: UFLA / FAEPE, $186 \mathrm{p}$.

FRESCHI L ET AL. 2010. Specific leaf areas of the tank bromeliad Guzmania monostachia perform distinct functions in response to water shortage. J Plant Physiol 167: 526-533.

FREY B. 2007. Botanical X-Ray Microanalysis in Cryoscanning Electron Microscopy. In: Kuo J, Methods in Molecular Biology ${ }^{\mathrm{TM}}$. Humana Press 369: 529-541.

HAZARIKA BN. 2006. Morpho-physiological disorders in in vitro culture of plants. Sci Hortic 108: 105-120.

KORNDÖRFER GH. 2006. Elementos benéficos. In: Fernandes MS, Nutrição mineral de plantas. Rev Bras Cienc Solo 14: 355-370.

KORNDÖRFER GH, PEREIRA HS AND NOLLA A. 2004. Análise de silício: solo, planta e fertilizante. GPSi-ICIAGUFU, Boletim Técnico, $50 \mathrm{p}$.

KOZAI T, XIAO Y, NGUYEN QT, AFREEN F AND ZOBAYED SMA. 2005. Photoautotrophic (sugar-free medium) micropropagation systems for large-scale commercialization. Propag Ornam Plants 5: 23-34.

LI H, TANG C AND XU Z. 2013. The effects of different light qualities on rapeseed (Brassica napus L.) plantlet growth and morphogenesis in vitro. Sci Hortic 150: 117-124.

LIU P, YIN L, DENG X, WANG S, TANAKA K AND ZHANG S. 2014. Aquaporin-mediated increase in root hydraulic conductance is involved in silicon-induced improved root water uptake under osmotic stress in Sorghum bicolor L. J Exp Bot 65: 47-56.

MALAVOLTA E, VITTI GC AND OLIVEIRA SA. 1997. Avaliação do estado nutricional das plantas: princípio e aplicações, $2^{\text {a }}$ ed., Potafos, 319 p.

MANIVANNAN A, SOUNDARARAJAN P, CHO YS, PARK JE AND JEONG BR. 2017. Sources of silicon influence photosystem and redox homeostasis-related proteins during the axillary shoot multiplication of Dianthus caryophyllus. Plant Biosyst 152: 704-710

MARTINS JPR, PASQUAL M, MARTINS AD AND RIBEIRO SF. 2015a. Effects of salts and sucrose concentrations on in vitro propagation of Billbergia zebrina (Herbert) Lindley (Bromeliaceae). Aust J Crop Sci 9: 85-91.

MARTINS JPR, SCHIMILDT ER, ALEXANDRE RS, CASTRO EM, NANI TF, PIRES MF AND PASQUAL M. 2014. Direct organogenesis and leaf-anatomy modifications in vitro of Neoregelia concentrica (Vellozo) L.B. Smith (Bromeliaceae). Pak J Bot 46: 2179-2187.

MARTINS JPR, VERDOODT V, PASQUAL M AND DE PROFT M. 2015b. Impacts of photoautotrophic and 
photomixotrophic conditions on in vitro propagated Billbergia zebrine (Bromeliaceae). Plant Cell Tissue Organ Cult 123: 121-132.

MATHE C, MOSOLYGO A, SURANYI G, BEKE A, DEMETER Z, TOTH VR, BEYER D, MÉSZÁROS I AND M-HAMVAS M. 2012. Genotype and explants-type dependent morphogenesis and silicon response of common reed (Phragmites australis) tissue cultures. Aquat Bot 97: 57-63.

MURASHIGE T AND SKOOG F. 1962. A revised medium for rapid growth and bioassays with tobacco tissue cultures. Physiol Plant 15: 473-497.

PARK SY, MOON HK, MURTHY HN AND KIM YW. 2011. Improved growth and acclimatization of somatic embryo-derived Oplopanax elatus plantlets by ventilated photoautotrophic culture. Biol Plant 55: 559-562.

PARVAIZ A AND SATYAWATI S. 2008. Salt stress and phyto-biochemical responses of plants - a review. Plant Soil Environ 54: 89-99.

PASQUAL M, SOARES JDR, RODRIGUES FA, ARAUJO AG AND SANTOS RR. 2011. Influência da qualidade de luz e silício no crescimento in vitro de orquídeas nativas e híbridas. Hortic Bras 29: 324-329.

PEDROSO ANV, LAZARINI RAM, TAMAKI V AND NIEVOLA CC. 2010. In vitro culture at low temperature and ex vitro acclimatization of Vriesea inflata an ornamental bromeliad. Braz J Bot 33: 407-414.

PRABAGAR S, HODSON MJ AND EVANS DE. 2011. Silicon amelioration of aluminium toxicity and cell death in suspension cultures of Norway spruce (Picea abies (L.) Karst.). Environ Exp Bot 70: 266-276.

PRADO RM. 2008. Nutrição Mineral de Plantas. São Paulo: Editora UNESP, 417 p.

RADI MR AND KARIMI N. 2012. The role of calcium in plants' salt tolerance. J Plant Nutr 35: 2037-2054.

RAVEN PH, EVERT RF AND EICHHORN SE. 2007. Biologia vegetal, $7^{\mathrm{a}}$ ed., Rio de Janeiro: Guanabara Koogan, 856 p.

REIDINGER S, RAMSEY MH AND HARTLEY SE. 2012. Rapid and accurate analyses of silicon and phosphorus in plants using a portable X-ray fluorescence spectrometer. New Phytol 195: 699-706.

RODRÍGUEZ-GAMIR J, INTRIGLIOLO DS, PRIMOMILLO E AND FORNER-GINER MA. 2010. Relationships between xylem anatomy, root hydraulic conductivity, leaf/root ratio and transpiration in citrus trees on different rootstocks. Physiol Plant 139: 159-169.

SAHEBI M, HANAFI MM AND AZIZI P. 2016. Application of silicon in plant tissue culture. In vitro Cell Dev Biol Plant 52: 226-232.

SCHAEDLE M. 1990. Nutrient uptake. In: Van den Driessche R (Ed), Mineral Nutrition of Conifer Seedlings. CRC Press LLC, p. 25-60.
SHAHZAD A, PARVEEN S, SHARMA S, SHAHEEN A, SAEED T, YADAV V, AKHTAR R, AHMAD Z AND UPADHYAY A. 2017. Plant Tissue Culture: Applications in Plant Improvement and Conservation. In: Abdin MZ, Kiran U, Kamaluddin M and Ali A (Eds), Plant Biotechnology: Principles and Applications. Springer Singapore, p. 37-71.

SIVANESAN I AND JEONG BR. 2014. Silicon promotes adventitious shoot regeneration and enhances salinity tolerance of Ajuga multiflora Bunge by altering activity of antioxidant enzyme. Sci World J 2014: 1-10.

SIVANESAN I AND PARK SW. 2014. The role of silicon in plant tissue culture. Front Plant Sci 5: 571.

SOARES JDR, PASQUAL M, RODRIGUES FA, VILLA F AND DE ARAUJO AG. 2011. Silicon sources in the micropropagation of the Cattleya group orchid. Acta Sci Agron 33: 503-507.

SOARES JDR, VILLA F, RODRIGUES FA AND PASQUAL M. 2013. Concentrations of silicon and GA3 in in vitro propagation of orchids under natural light. Sci Agrar Parana 12: 286-292.

SOUNDARARAJAN P, MANIVANNAN A, PARK YG, MUNEER S AND JEONG BR. 2015. Silicon alleviates salt stress by modulating antioxidant enzyme activities in Dianthus caryophyllus 'Tula'. Hortic Environ Biotechnol 56: 233-239.

STREIT NM, CANTERLE LP, CANTO MW AND HECKTHEUER LHH. 2005. As clorofilas. Cienc Rural 35: 748-755.

TESTER M AND DAVENPORT R. 2003. $\mathrm{Na}^{+}$tolerance and $\mathrm{Na}^{+}$transport in higher plants. Ann Bot 91: 503-527.

TOMBOLATO AFC AND COSTA AMM. 1998. Micropropagação de plantas ornamentais. Campinas: Instituto Agronômico, Boletim Técnico 174: 72.

ULISSES C, CAMARA TR, WILLADINO L, ALBUQUERQUE CC AND BRITO JC. 2010. Early somatic embryogenesis in Heliconia chartacea Lane ex Barreiros cv. Sexy Pink ovary section explants. Braz Arch Biol Technol 53: 11-18.

VESCO LLD, STEFENON VM, WELTER LJ, SCHERER RF AND GUERRA MP. 2011. Induction and scale-up of Billbergia zebrina nodule cluster cultures: implications for mass propagation, improvement and conservation. Sci Hortic 28: 515-522.

WATANABE S, KOJIMA K, IDE Y AND SASAKI S. 2000. Effects of saline and osmotic stress on proline and sugar accumulation in Populus euphratica in vitro. Plant Cell Tissue Organ Cult 63: 199-206.

ZHU Y AND GONG H. 2014. Beneficial effects of silicon on salt and drought tolerance in plants. Agron Sustain Dev 34: 455-472. 